\title{
Dynamics of Mango Seedlings and Mango Varieties: A Case Study of Nurseries in Mango Production Center in Majalengka, West Java, Indonesia ${ }^{+}$
}

\author{
Puspitasari ${ }^{1, *}$, Sara Ratna Qanti ${ }^{2}$ and Hardiyanto ${ }^{1}$ \\ 1 Indonesian Center for Horticulture Research and Development, 16111 Bogor, Indonesia; \\ hardiyanto85@yahoo.com \\ 2 Social and Economic of Agriculture Departmen, Padjajaran University, 40623 Bandung, Indonesia; \\ saraqanti@gmail.com \\ * Correspondence: puspitasari_ak@yahoo.com \\ + Presented at the third International Tropical Agriculture Conference (TROPAG 2019), Brisbane, Australia, \\ 11-13 November 2019.
}

Published: 11 January 2020

\begin{abstract}
Mango is a favorite tropical fruit in both domestic and international markets. Due to its features that are relatively easy to grow and more resistant to pests and diseases, the success rate of producing the seedlings is higher compared to the other perennial fruit plants. Despite of these advantages, the sector is still facing several constrains. One of them is the low rate of certified seedling used that may affects the productivity of mango trees. Limited availability of superior certified mango seedlings that is faced by mango nurseries is suspected as one of the cause. This paper aims to describe the dynamic that occurs in mango nursery sector in one of mango production centres in West Java. The data was collected through survey of 260 nurseries in 2016 and was part of Indohort project research; a collaboration between Australian Centre for International Agricultural Research (ACIAR), Iindonesian Center for Horticulture Research and Development (ICHORD), and the University of Adelaide. The results showed that: (1) Only 7\% of the total number of nurseries has a formal certification for seedlings that are produced, (2) in average, mango nurseries produce less mango seedlings in 2016 compared to 2011; (3) mango nursery's specialization rate decreased from 32\% in 2011 to 19\% in 2016, (4) the share of Harumanis (mango variety that is most preferred in Indonesia) seedlings production per nursery, decreased from $89 \%$ in 2011 to $65 \%$ in 2016; (4) Further improvement related to mango seedlings marketting chain needs to be done to create a better mango seedling market structure along the chain.
\end{abstract}

Keywords: mango; seedlings; varieties; nurseries

Funding: This research was funded by Australian Centre for International Agricultural Research (ACIAR), project number AGB/2009/060

Acknowledgments: We acknowledge the support provided by Indohort project team Prama Yufdy, Idha Widi Arsanti, Henri Wira Perkasa and Rizka Amalia Nugrahapsari

Conflicts of Interest: The author declares no conflict of interest.

(C) 2020 by the authors. Licensee MDPI, Basel, Switzerland. This article is an open access article distributed under the terms and conditions of the Creative Commons Attribution (CC BY) license (http://creativecommons.org/licenses/by/4.0/). 